\title{
STUDI PENGGUNAAN APLIKASI PADLET PADA KELAS MENULIS
}

\author{
Arina Rohmatika, ${ }^{1}$ Puput Arianto, ${ }^{2}$ Rangga Maysa Putra, ${ }^{3}$
}

\begin{abstract}
Abstrak
Pengajaran Bahasa Inggris khususnya menulis selalu mempunyai tantangan tersendiri di Indonesia. Seiring dengan berkembangnya teknologi, makin banyak apliaksi yang banyak digunakan sebagai media pembelajaran Bahasa Inggris. Salah satu aplikasi yang banyak digunakan dalam pengajaran Bahasa Inggris adalah aplikasi Padlet. Penelitian ini bertujuan untuk mendeskripsikan Implementasi, masalah dan solusi terhadap penggunaan Aplikasi Padlet pada kelas menulis pada mahasiswa semester pertama Program Studi Pendidikan Bahasa Inggris IAIN Surakarta, Tahun Akademik 2019/2020. Data dikumpulkan melalui observasi, wawancara dan dokumentasi pada buku padlet dosen dan mahasiswa. Analisis data dilakukan melalui proses pengumpulan data, reduksi data, penyajian data dan penarikan kesimpulan dan verifikasi. Hasil penelitian menunjukkan bahwa penggunaan aplikasi Padlet pada kelas menulis menunjukkan hasil yang positif khususnya pada proses Brainstorming. Permasalahan utama yang terjadi selama implementasi Aplikasi Padlet lebih kepada masalah teknis dimana mahasiswa kurang familiar/ memahami fitur Padlet itu sendiri. Selain itu, masalah jaringan yang tidak stabil juga menjadi kendala bagi Sebagian besar mahasiswa. Evaluasi rutin di kelas dengan mengecek tugas secara tertulis, mencari referensi di Aplikasi Padlet serta memanfaatkan koneksi WIFI di kampus untuk mendapatkan sinyal yang lebih stabil dan baik terbukti menjadi solusi bagi permasalahan yang ada.

Kata Kunci: Menulis, Aplikasi Padlet, Pengajaran Bahasa Inggris
\end{abstract}

\begin{abstract}
Teaching English, especially writing, always has its own challenges in Indonesia. Along with the development of technology, more and more applications are widely used as a medium for learning English. One application that is widely used in teaching English is the Padlet. This study aims to describe the implementation, problems and solutions to the use of the Padlet application in the writing class of the first semester students of the IAIN Surakarta English Education Study Program, 2019/2020 Academic Year. Data were collected through observation, interviews and documentation from the Padlet books of lecturers and students. Data analysis was carried out through the process of data collection, data reduction, data presentation and conclusion and verification. The results showed that the use of the Padlet application in the writing class showed positive results, especially in the Brainstorming process. The main problems that occur during the implementation of the Padlet Application are more technical problems where students are not familiar with / understand the features of Padlet itself. Besides that, the problem of the unstable network was also an obstacle for most students. Routine evaluation in class by checking assignments in writing, looking for references on the Padlet Application and utilizing a WIFI connection at the University to get a better signal has proven to be a solution to existing problems.

Keywords: Writing, Padlet Application, English Language Teaching
\end{abstract}

\footnotetext{
${ }^{1}$ IAIN Surakarta, email: arina.rohmatika@iain-surakarta.ac.id

${ }^{2}$ IAIN Surakarta, email: puput.arianto@iain-surakarta.ac.id

${ }^{3}$ IAIN Surakarta, email: ranggaputra1196@gmail.com
} 


\section{Pendahuluan}

Bahasa inggris, telah menjadi fokus empat kemampuan harus dikuasai saat seseorang belajar bahasa. Di antara keterampilan tersebut, menulis adalah yang paling sulit seperti Togatorop (2015: 247256) mengatakan bahwa menulis adalah yang paling sulit dari empat keterampilan bahasa (berbicara, mendengarkan, membaca, dan menulis). Pernyataannya didukung oleh beberapa ahli diantaranya Nunan (1995: 133-158), Brown (2001), dan Harmer (2007) yang mengatakan bahwa menulis merupakan kegiatan yang sangat kompleks karena komponennya yang rumit seperti pengembangan ide, sintaksis, tata bahasa organisasi, kosakata, konten, keterampilan komunikasi, dan penggunaan tanda baca.

Menulis adalah salah satu dari empat kemampuan, yang memiliki kasus vital dan kemampuan paling menyusahkan dalam bahasa Inggris. Kay dalam Westwood (2004: 100) menyatakan bahwa menulis adalah proses yang sangat kompleks yang melibatkan banyak mekanisme otak dan kemampuan tertentu. Tindakan menulis mengharuskan penulis untuk merumuskan ide, mengatur dan mengurutkan poin dalam urutan logis, memilih kosakata, dan memeriksa ketepatan tata bahasa, mengeja kata dengan benar, memberi tanda baca, dan menulis dengan jelas. Banyak siswa tidak pernah diminta untuk mempelajari ejaan atau tata bahasa yang benar sehingga mereka percaya bahwa mereka tidak akan pernah mencapai hasil.

Menulis salah satu kemampuan dasar yang harus dikuasai oleh siswa. Menurut Brown (2004: 218), menulis merupakan suatu keterampilan yang menjadi domain eksklusif ahli Taurat dan sarjana di lembaga pendidikan atau agama. Hampir setiap bagian dari kehidupan seharihari biasa bagi individu "normal" dilakukan secara lisan. Pertukaran bisnis, catatan, dokumen yang valid, penerimaan politik dan militer - semuanya ditulis oleh seorang master yang pekerjaannya adalah menyampaikan bahasa ke dalam kata-kata tertulis.

Individu perlu belajar menulis untuk menghadapi sains dan kemajuan modern. Kemudian lagi, individu perlu menulis sesuatu untuk membuat korespondensi untuk pekerjaan atau tujuan keilmuan, terutama untuk siswa. Mereka harus mengambil kemampuan menulis untuk berbicara dengan orang lain dan mengatur diri mereka sendiri untuk tugas terakhir dan peraturan mereka untuk apa yang akan datang.

Dalam belajar menulis, siswa menghadapi beberapa masalah.Berdasarkan Langan (2005: 13) banyak orang mengalami kesulitan untuk melakukan intens pada 
menulis, berpikir aktif sehingga menulis jernih. Berdasarkan observasi peneliti prapenelitian, sebagian dari siswa mengalami masalah di kelas menulis; Ada struktur tata bahasa, ejaan kata, dan tanda baca. Kesalahan penggunaan tenses dan kalimat pasif juga ditemukan dalam tulisan siswa. Selain itu, ketiadaan kosakata dan tidak adanya informasi menyebabkan mereka merasa repot dalam melakukan brainstorming dan menciptakan pemikiran.

Umumnya, mereka hanya menulis pemikiran yang serupa dan secara konsisten mengulang kata yang serupa di konten. Siswa tidak dapat menciptakan pemikiran karena siswa terjebak pada satu ide. Pada saat siswa tidak dapat membangun ide, hal ini tersirat bahwa siswa membutuhkan strategi kreatif, media baru, dan kemajuan dalam proses pembelajaran mendidik. Proses pembelajaran yang mendidik akan dibantu oleh strategi dan media kreatif.

Untuk mengatasi hal tersebut diperlukan peran dosen. Dosen harus memanfaatkan strategi kreatif atau media baru bagi mahasiswanya agar mahasiswa lebih menarik dan memiliki minat yang baik dalam menulis. Untuk situasi ini, ketika dosen sejak dulu memanfaatkan strategi kreatif yang dapat membuat mahasiswa berubah, maka peran media penting bagi mahasiswa.
Arsyad menyatakan bahwa (2006: 4) media adalah aksesoris yang dapat mengirimkan dan menyampaikan pesan pembelajaran. Individu dapat berbagi pemikiran, tujuan perspektif atau argumen melalui media. Menurut Santyasa (2007: 3), media adalah alat yang dapat digunakan untuk mentransfer materi pembelajaran sehingga dapat merangsang perhatian, minat, pemikiran, dan perasaan siswa dalam proses pembelajaran dalam mencapai tujuan pembelajaran.

Dalam proses belajar mengajar, media benar-benar diperlukan. Media tidak hanya sekedar menyampaikan pesan pembelajaran tetapi juga dalam beberapa hal memudahkan siswa dalam belajar. Media bisa disebut sebagai alat transfer informasi dan diharapkan seseorang yang mendapat informasi tersebut menemukan.Saat ini, individu tidak hanya memanfaatkan media sosial sebagai perangkat yang terhubung di lingkungan sosial tetapi juga di bidang pendidikan.

Deni dan Zainal (2015: 364-369) menyatakan bahwa Messenger, Facebook, Blog, Twitter, dan Padlet direkomendasikan untuk dijadikan jejaring sosial di bidang pendidikan. Menurut Algraini (2014: 16) Padlet adalah situs jejaring sosial gratis di mana orang dapat berdebat atau berdiskusi tentang topik tertentu dan dengan mudah menggunakan elemen multimedia untuk 
menyempurnakan kata-kata mereka. Padlet adalah dinding online berbasis webtempat ide dikumpulkan melalui pos virtual dari pengguna (Shield, 2014: 92-93).

Padlet merupakan sebuah aplikasi yang memungkinkan penggunanya untuk mengunggah gambar, video, dokumen dan PDF, berbagi tautan, mengomentari kiriman satu sama lain, membuat dinding publik atau pribadi, dan bertukar informasi. Ini adalah dinding online yang memberi pengguna sejumlah fitur bagus yang memfasilitasi komunikasi di antara orangorang dan merangsang mereka untuk mengekspresikan diri. Untuk menggunakan aplikasi ini, pengguna dapat menggunakan perangkat apa pun yang memungkinkan untuk terhubung ke internet seperti ponsel pintar, komputer, iPad, atau perangkat lainnya.

Pengguna dapat menikmati aplikasi tanpa mendaftar atau membuat akun, namun akan lebih menguntungkan bagi pengguna jika membuat akun. Pengguna dapat membuat dinding tanpa batas, mengundang orang lain untuk bekerja sama di dinding mereka, menyesuaikan dan mengelola privasi di Padlet mereka hanya dengan menggunakan akun gratis (Fiester \& Green, 2016: 404-408). Karena membuat akun dapat membantu pengguna dalam mengatur interaksi dan performanya (Haris, 2017: 783-788). Email akan dikirim untuk memberi tahu guru setiap kali siswa menanggapi dinding guru (Wood, 2016). Ketika seseorang memberikan respon di wall pengguna, maka akan ada notifikasi di email pengguna.

Di IAIN Surakarta, Aplikasi Padlet sudah banyak dimanfaatkan dalam proses pembelajaran Bahasa Inggris khususnya untuk mata kuliah Menulis. Dosen memanfaatkan aplikasi Padlet sebagai media pelengkap dalam kelas menulis. Padlet digunakan sebagai media untuk mengumpulkan hasil tugasnya secara individu atau kelompok dan diserahkan pada Aplikasi Padlet. Dosen memanfaatkan aplikasi Padlet agar mahasiswa lebih mengapresiasi dan antusias dalam proses pembelajaran mendidik. Mahasiswa juga dapat menunjukkan informasi dari tanggapan dosen. Dalam aplikasi Padlet, siswa dapat mengumpulkan tugas dengan lebih sederhana. Siswa dapat memanfaatkan Aplikasi Padlet untuk membuat brainstorming atau konsep pohon.

\section{Metode}

Penelitian ini merupakan studi kualitatif deskriptif. Dikenal sebagai studi deskriptif karena dalam prosesnya, peneliti mencari data, mengumpulkan data, mengklasifikasikannya, menganalisisnya, dan akhirnya menarik kesimpulan tentang data tersebut (Surakhmad, 1994: 147). 
Menurut Borg dan Gall (1989) dalam Sugiyono (2015: 3), penelitian kualitatif disebut sebagai metode baru, post positivistik, penemuan, interpretatif dan kualitatif. Berdasarkan Sugiyono (2015: 15) penelitian kualitatif merupakan metode penelitian yang berbasis post positivistik, digunakan untuk penelitian pada obyek alam, (sebagai musuhnya adalah Eksperimen).

Peneliti sebagai instrumen utama, mengumpulkan contoh, sumber data yang digunakan sebagai tujuan dan Snowball, mengumpulkan data yang digunakan dengan triangulasi, menganalisis data yang memiliki kualitas induktif dan hasil datanya lebih mengarah pada penjelasan daripada spekulasi. Studi kualitatif deskriptif adalah metode deskripsi yang memperhatikan kasus-kasus tertentu di mana data yang dikumpulkan diklasifikasikan, dianalisis, dan dijelaskan. Inti dari metode ini adalah untuk menggambarkan apa yang sebenarnya terjadi dalam keadaan dan kondisi tertentu. Lebih lanjut, Subjek dalam penelitian ini diambil dari satu dosen pengampu mata kuliah writing dan mahasiwa semester pertama di Prodi Pendidikan Bahasa Inggris IAIN Surakarta sebanyak dua kelas dengan jumlah total 60 mahasiswa.
Teknik pengumpulan data dilakukan dengan observasi, wawancara, dan dokumentasi. Jenis wawancara yang digunakan dalam observasi ini adalah wawancara semi struktur. Berdasarkan Sugiyono (2015: 320), pada jenis wawancara yang tergolong dalam kategori wawancara mendalam; pelaksanaan jenis ini lebih bebas daripada wawancara terstruktur. Tujuan di balik jenis ini adalah untuk menemukan informasi terbaru dari narasumber. Dalam wawancara semacam ini, peneliti mempersiapkan pertanyaan apa yang akan diajukan sebelum wawancara diarahkan dan pertanyaan tersebut mungkin berkembang selama wawancara dan pertanyaan baru dapat muncul bergantung pada kemajuan wawancara dan keadaan. Pertanyaan baru berdasarkan daftar kemungkinan akan dimasukkan jika peneliti mendapat informasi baru dari daftar yang telah direncanakan. Inti dari penyortiran ini adalah untuk mendapatkan informasi detail dari penanya.

Dalam menganalisis data, peneliti menggunakan penelitian deskriptif kualitatif. Dengan menggunakan teknik tersebut, peneliti mengumpulkan data, menyusun data, kemudian menyiapkan data. Metode kualitatif adalah studi tanpa menggunakan sistem penilaian atau pengukuran apa pun. Proses analisis data 
digambarkan oleh Miles dan Huberman (1984: 22) pada gambar berikut.

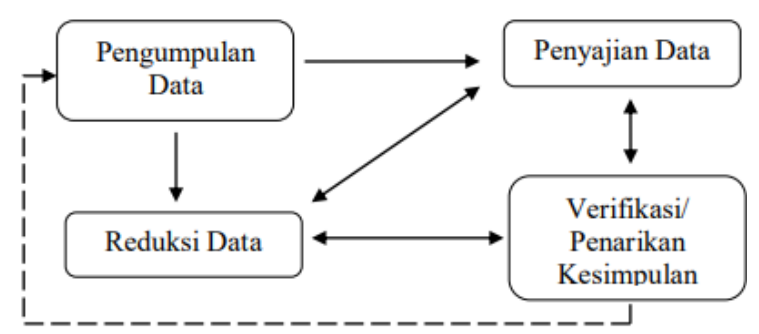

Ilustrasi Model Interaktif

oleh Miles \& Huberman

(1984: 22)

Miles \& Huberman (1984: 22) menguraikan empat jenis analisis data berupa proses interaktif yaitu menganalisis data kualitatif sebagai berikut; Peneliti mewawancarai informan dan melakukan observasi terhadap penerapan Aplikasi Padlet yang digunakan guru dalam kelas menulis pada mahasiswa semester pertama Jurusan Pendidikan Bahasa Inggris. Selain itu, peneliti meminta bukti dari Aplikasi Padlet untuk dokumentasi dari dosen dan mahasiswa.

Selanjutnya adalah proses Pengurangan data. Mengurangi data artinya meringkas, memilih, hal-hal yang mendasar, memfokuskan pada hal-hal yang penting, mencari tema dan pola serta menghilangkan yang tidak perlu. Peneliti melakukan reduksi data yaitu melalui wawancara dan observasi kepada dosen dan mahasiswa. Melalui wawancara dan observasi yang dilakukan oleh peneliti, diperlukan reduksi data karena tidak seluruh data dapat diterima sebagai kebutuhan dalam penelitian, hanya poin yang dibutuhkan dan penting serta berdasarkan kebutuhan data diperiksa. Peneliti mengurangi data wawancara bahwa peneliti hanya memanfaatkan data yang terbaik untuk menelaah secara mendalam.

\section{Tampilan Data}

Data tersebut akan mengecil dan kemudian membuat tampilan data. Penyajian data dapat berupa penggambaran singkat, diagram, hubungan antar kelas, dll. Jenis data yang paling sering disajikan untuk data penelitian kualitatif pada masa sebelumnya adalah teks deskriptif. Melalui tampilan data, kemudian data diatur, diatur dalam contoh koneksi yang akan dipahami secara sederhana. Peneliti memilah data dan menggambarkan implementasi Aplikasi Padlet yang dimanfaatkan oleh dosen pada kelas menulis karangan dan karangan pada mahasiswa semester pertama program studi Pendidikan Bahasa Inggris. Kesimpulan: Menggambar dan Verifikasi

Penarikan dan pembuktian yang mengandung kesimpulan primer masih bersifat spekulatif dan akan berubah jika tidak ditemukan bukti yang membantu pengumpulan data yang solid pada tahap selanjutnya. Kesimpulan dalam penelitian kualitatif mungkin memiliki pilihan untuk 
menjawab masalah penelitian yang diteliti sejak dini. Karena biasanya, dengan alasan seperti yang telah diungkapkan permasalahan dalam penelitian kualitatif masih bersifat kondisional dan akan tercipta dalam penelitian.

Dalam tahap ini, peneliti membuat keputusan yang mendasari tentang penerapan Aplikasi Padlet yang akan dimanfaatkan oleh dosen dalam mata kuliah penulisan karangan dan karangan. Kesimpulan yang mendasari memiliki pilihan untuk mencapai pertanyaan penelitian tergantung pada penelitian kualitatif yang diperoleh dari observasi, wawancara dan dokumentasi. Dari penjelasan diatas, peneliti menerapkan strategi ini untuk menggambarkan dan menganalisis data dari hasil atau kajian tentang penerapan Aplikasi Padlet pada kelas menulis karangan dan karangan pada mahasiswa semester pertama program studi pendidikan bahasa Inggris secara efisien, sehingga penelitian ini akan menjadi dapat diterima.

Untuk mengetahui keterpercayaan data, peneliti membutuhkan beberapa teknik pemeriksaan data. Ujian dilakukan berdasarkan beberapa kriteria. Ada empat kriteria penggunaan: kredibilitas, transferabilitas, ketergantungan, dan kesesuaian. Dalam penelitian ini peneliti akan menggunakan triangulasi. Menurut
Sutopo (2006: 92-99), triangulasi adalah suatu teknik memeriksa keterpercayaan data dengan menggunakan sesuatu yang tidak termasuk data untuk memeriksa atau membandingkan data. Triangulasi dibagi menjadi empat teknik: (1) triangulasi data (2) triangulasi penyidik (3) triangulasi metodologi (4) triangulasi teoritis.

Dalam penelitian ini, peneliti menggunakan triangulasi metodologis. peneliti memeriksa dari data yang diambil dari observasi dan wawancara dan informasi tersebut sampai ke dokumentasi, untuk situasi ini, antusiasme mahasiswa terhadap tugas di Aplikasi Padlet. Selanjutnya, Peneliti membandingkan data hasil observasi yang dilakukan selama proses belajar mengajar dengan data hasil wawancara dan dokumentasi yang memiliki sumber data serupa. Sejalan dengan itu, penelitian ini akan dapat dipercaya.

\section{Penggunaan Aplikasi Padlet Pada}

\section{Kelas Menulis.}

Pada studi ini, peneliti menjelaskan bagaimana cara dosen memanfaatkan Aplikasi Padlet untuk kelas menulis. Peneliti menjelaskan tahapan-tahapan dosen mnegajar dengan menggunakan Padlet dari mulai dari awal sampai akhir. Tahap pertama adalah tahap Presentasi Aplikasi. Dalam tahap ini, dosen menjelaskan aplikasi Padlet mulai dari pengertian, fitur, kelemahan, kelebihan yang ada pada 
aplikasi Padlet. Dosen juga menjelaskan salah satu fitur submit dan post yang ada di aplikasi Padlet. Pada aplikasi Padlet dosen juga menjelaskan bahwa mahasiswa harus membuat akun Padlet, mengomentari akun Padlet sendiri atau Padlet teman, mengedit postingan yang sudah anda buat. Buatlah dinding Padlet semenarik mungkin agar dosen dan mahasiswa lainnya dapat merespon tulisan di dinding Padlet tersebut. Tahap berikutnya adalah Penyampaian materi. Pada sesi ini, dosen melakukan kegiatan pembelajaran menulis masih menggunakan metode klasikal seperti biasa. Aplikasi Padlet digunakan untuk media pengelolaan tugas-tugas siswa. Aplikasi padlet hanya digunakan sebagai pendukung dan bukan aktivitas utama di kelas. Pada sesi ini, terlebih dahulu dosen menjelaskan kepada mahasiswa seluruh isi materi tulisan, dosen menawarkan latihan kepada siswa di kelas. Sebelumnya, siswa telah mendapat tugas di Aplikasi Padlet sehingga Ketika sesi penyampaian materi telah selesai, mereka bisa langsung membuka aplikasi. Hal ini cukup efektif terkait dengan penggunaan waktu. Materi tambahan juga diberikan di luar Padlet sebagai pengayaan, mahasiswa diminta untuk mendownload materi pendukung.

\section{Pengerjaan Tugas Dalam Aplikasi Padlet.}

Pada tahap ini, mahasiswa harus mengerjakan tugas dalam aplikasi Padlet setelah instruksi dan penjelasan materi diberikan. Hampir di setiap pertemuan, dosen memberikan tugas dalam aplikasi Padlet. Dosen secara kontinu memberikan tugas dan mahasiswa mengerjakannya dalam Aplikasi Padlet. Untuk meningkatkan motivasi mahasiswa, dosen meyampaikan bahwa kecepatan pengumpulan tugas dan kualitas isi tulisan menjadi factor penting dalam penilaian sehingga dengan strategi ini mahasiswa bsia menjadi lebih bersemangat dalam menyelesaikan tugas dan memastikan kualitas isi tulisan juga. Strategi ini tampak berhasil dilihat dari kualitas tulisan yang masuk dari mahasiswa yang mensubmit awal.

\section{Tanggapan Atau Respon Tugas.}

Respon diberikan oleh dosen dan juga mahasiswa di kelas atau di Aplikasi Padlet. Dosen memberikan tanggapan kepada mahasiswa tentang tugasnya. Pada sesi ini, dosen juga meminta mahasiswa untuk saling memberikan kome ntar dan respon akan tugas temannya. Hal ini dilakukan daklam rangka mendorong keaktifan siswa dan juga melatih kebiasaan peer-checking (saling memeriksa tugas) sekaligus melatih kemampuan berfikir kritis mahasiswa. 
Dosen dalam hal ini tidak hanya berperan sebagai evaluator tetapi juga fasilitator.

Hal tersebut terlihat sangat baik saat dosen memberikan materi dalam aplikasi Padlet. Dosen menyampaikan beberapa topik yang berhubungan dengan materi penulisan dan mahasiswa diminta untuk membicarakan topik tersebut. Dosen mempostingnya sebelum proses belajarmengajar di kelas. Percakapan online melalui Aplikasi Padlet dilakukan antara dosen dan mahasiswa. Keaktifan mahassiwa dalam berkomentar, mulai dari pemberian “ like" sampai dengan yang menyerahkan tugas lebih awal bisa menjadi salah satu indicator untuk melihat antusiasme mahasiswa.

Padlet bisa digunakan untuk mengukur seberapa antusias mahasiswa terhadap kegiatan menulis dalam perkuliahan; misalnya pada saat tugas dikirim, bisa dipastikan tanggal berapa, dan semakin aktif ada, siapa yang kekurangan tenggat.Dosen menyampaikan bahwa dengan menggunakan Padlet, dosen dan mahasiswa memiliki keterkaitan dan bisa berbicara tentang apa saja. Ia mengklarifikasi bahwa dari Padlet Application ia bisa mengetahui antusiasme mahasiswa. Dari pengiriman tugas, dosen dapat menyadari bahwa mahasiswanya aktif atau tidak. Jika siswa mengirim lebih cepat daripada teman sekelasnya, hal itu dapat menunjukkan bahwa siswa tersebut aktif di kelas.

\section{Keaktifan Di Kelas.}

Selama menggunakan apliaksi Padlet, tampak banyak interaksi yang dilakukan antara dosen dengan mahasiswa. Dalam interaksi ini, dosen berperan lebih aktif dalam mengendalikan aplikasi Padlet. Dosen memantau dan memandu kelas online agar diskusi terus berlangsung selama jam perkuliahan. Menurut Russel (2005), ia mengemukakan bahwa dalam pembelajaran online, peran dosen dapat bergeser menjadi fasilitator daripada memimpin kelas secara langsung. Penelitian ini menekankan bahwa siswa bebas untuk memperoleh dari berbagai sumber di web. Dalam hal ini, penggunaan aplikasi Padlet oleh dosen sangatlah relevan dimana mahasiswa dapat mengakses materi pembelajaran sebagai sumber untuk mereka berdiskusi Aplikasi Padlet.

Lebih lanjut, dari sisi mahasiswa, mereka diposisikan menjadi peserta dalam Aplikasi Padlet. Mereka diminta berkolaborasi saat dosen menyampaikan topik pembahasan, materi atau tugas. Dosen memberikan pembahasan topik kepada mahasiswa agar dapat saling berkolaborasi. Siswa akan memiliki pilihan untuk menyampaikan apa yang ada dalam gagasan mereka. Mahasiswa diminta untuk aktif dalam aplikasi Padlet mengingat dosen 
memanfaatkan Padlet untuk membantu mereka dalam belajar menulis. Mahasiswa terlihat antusias saat dosen menyampaikan materinya. Mereka memiliki keaktifan yang cukup bagus yang tampak dari jumlah komentar dan jumlah siswa yang aktif terlibat saat pertemuan dimulai. Beberapa mahasiswa bahkan telah menunggu postingan dosen di aplikasi Padlet. Antusiasme mahasiwa ini juga terlihat disaat waktu yang ditentukan untuk menyerahkan tugas. Mereka menyerahkan tugasnya di Padlet tepat waktu. Tugas selalu terkumpul kurang dari 24 jam walaupun tidak ada instruksi khusus terkait dengan Batasan waktu. Hal ini tentu menjadi catatan positif dari kolaborasi antara fungsi dosen sebagai fasilitator dengan fitur fitur yang dimiliki oleh Padlet.

Hal ini dimungkinkan karena memang Aplikasi Padlets sendiri memiliki opsi untuk mengirim dan berkomentar. Itu tidak terlalu sulit dilakukan oleh siswa yang memiliki akun email. Walaupun mahasiswa hanya sebagai pengunjung dan anggota kelompok, mereka tetap bisa membaca semua yang diposting oleh dosen di Aplikasi Padlet. Kombinasi antara kelas klasikal dan Padlet memberikan hasil yang bagus dalam kelas menulis. Pada saat di kelas, siswa perlu bekerja membuat beberapa paragraf tentang materi menulis, berlatih di depan kelas, mendapat respon setelah praktik, mengerjakan tugas secara individu atau kelompok. Sementara di Padlet, meraka dapat berdiskusi, mendapat masukan- masukan yang lebih terorganisir.

Dari pernyataan di atas, dosen mengklarifikasi bahwa mahasiswa memiliki keaktifan yang cukup baik dalam memanfaatkan aplikasi Padlet. Hal ini terlihat dari siswa mengumpulkan tugas tepat waktu. Siswa senang memanfaatkan aplikasi Padlet hingga mereka mengetahui teknik pembelajaran menulis dengan memanfaatkan aplikasi Padlet.

\section{Masalah pada Implementasi Aplikasi Padlet}

Masalah yang dibahas disini dalam masalah yang terjadi pada saat implementasi Aplikasi Padlet. Masalah yang paling sering muncul adalah masalah yang terkait dengan sistem, misalnya, saat mendaftar, mengumpulkan tugas dan koneksi yang buruk. Permasalahan utama adalah sign up. Padlet merupakan aplikasi baru untuk mahasiswa semester pertama, sehingga mahasiswa harus mempelajari aplikasi Padlet dari tahap awal hingga mampu memanfaatkannya. Mendaftar adalah langkah awal ketika individu perlu menggunakan Aplikasi Padlet. Mendaftar adalah masalah pertama dari siswa, siswa menemukan masalah membuat akun. Mereka tidak dapat menggunakan aplikasi Padlet untuk pertama kali. Padahal, saat 
siswa mendaftar, siswa kesulitan membuat akun. Siswa kesulitan membuat akun tentang membuat kata sandi, kata sandi tidak dapat digunakan atau kata sandi tidak cukup panjang. Masalah klasik seperti ini terlihat masih menjadi kendala bagi subjek penelitian.

Masalah kedua adalah pengumpulan tugas pada Aplikasi Padlet karena aplikasi baru Padlet untuk mahasiswa semester pertama. Mereka masih baru terhadap aplikasi tersebut sehingga siswa sulit untuk memisahkan fitur-fitur yang ada pada Aplikasi Padlet. Siswa sering bingung bagaimana cara mengumpulkan tugas, memanfaatkan ikon kirim atau posting. Meski sudah dijelaskan dosen sebelumnya, masih ada mahasiswa yang kesulitan mengumpulkan tugas. Siswa juga mempunyai kekhawatiran tentang kemungkinan tugas mereka tidak dapat dikirim ke Padlet dosen. "Kirim" adalah salah satu fitur kumpulkan tugas di aplikasi Padlet.

Siswa justru sering kebingungan saat menggunakan icon submit dan icon posting. Keduanya adalah fitur untuk mengumpulkan tugas. Ketika mahasiswa memilih ikon posting, ia mengirim ke dosen dan mahasiswa Padlet tetapi ketika mahasiswa memilih ikon kirim, ia hanya mengirim ke akun Padlet dosen. Masalah ketiga adalah isi tugas. Dengan menggunakan padlet, mahasiwea bisa mengirikna tugas kapan sja dan dari mana saja. Bahkan ada apresiasi bagi yang mengirim lebih awal dan yang memiliki kualitas isi yang bagus. Faktanya, masih banyak mahasiswa yang ingin mengumpulkan lebih awal tanpa mengecek kualitas tulisan. Terkadang siswa yang mengirim dengan cepat, tidak terlalu peduli dengan isi tugas. Mereka lebih fokus pada submit cepat agar mendapat nilai tambahan. Dari sini, dosen harus secara konsisten mengecek kualitas tugas dan terus mengingatkan mahasiswa akan poin utama penilaian yaitu kualitas tulisan.

Masalah keempat adalah pre-writing dalam brainstorming ide. Siswa banyak mengalami masalah ketika berada di tahap awal proses menulis ini. Mereka serig kesulitan dalam mulai mencari ide tentang suatu topik, siswa tidak mendapatkan banyak referensi jika mulai mengembangkan tulisan pada suatu topik tertentu. Kendala ini dirasa berat bagi mahasiwa Ketika mereka harus bekerja secara individu. Mereka kesulitan untuk membayangkan atau mengungkapkan tulisan mereka secara spontan. Sumber atau referensi tertulis tidak banyak. Oleh karena itu, dari proses prewriting hingga brainstorming, mereka merasakan adanya masalah. 
Masalah terakhir adalah ketika mahasiswa tidak memeliki jaringan ineternet yang bagus dan stabil. Mereka akan sangat bingung dan panik ketika koneksi mereka buruk. Siswa harus menggunakan koneksi yang layak untuk masuk ke aplikasi Padlet. Pada saat siswa mendapat sinyal buruk, siswa tidak bisa masuk di Aplikasi Padlet. Siswa tinggal menunggu sampai sinyal membaik dan bisa masuk di Aplikasi Padlet. Sesuai pernyataan siswa, ia mengatakan bahwa yang menjadi persoalan, saat ia ingin mengambil tugas itu isyarat buruk. Jaringan internet adalah bagian penting ketika menggunakan media online khususnya menggunakan aplikasi Padlet.

Siswa lain menyatakan bahwa sinyal berpengaruh besar terhadap pengiriman tugas. Ketika dia mendapat sinyal yang bagus, dia akan segera mengirim tugas, tetapi ketika dia mendapat sinyal yang buruk, dia akan mendapat masalah dengan tugas yang dikirim. Dapat dikatakan disini bahwa sering terjadi gap antara apa yang dosen dan mahasiswa perlu capai sebagai tujuan pengajaran dan terjadi mengingat berbagai masalah yang berdampak dalam mewujudkan tujuan tersebut. Sebagaimana yang diungkapkan Ahmadi dan Uhbiyati (2001) tentang macam-macam masalah yang berkaitan dengan media pembelajaran:
Permasalahan "Who" berkaitan dengan guru dan siswa dalam menggunakan media. Permasalahan "Why" terkait dengan penalaran dalam penerapan media. Permasalahan "Dimana" terkait dengan tempat pemanfaatan media. Permasalahan “Kapan” terkait dengan setting waktu dalam penyelenggaraan media. Permasalahan "Apa" terkait dengan dasar, tujuan dan materi pembelajaran dari media itu sendiri. Permasalahan "Bagaimana" terkait dengan cara / metode yang digunakan dalam proses penggunaan media.

Dalam penelitian ini, dosen tidak menghadapi semua masalah di atas dalam penggunaan Aplikasi Padlet di kelas menulis. Masalah yang sering muncul lebih banyak terkait dengan "Bagaimana”. Dosen mendapat tantangan untuk bisa memberikan Informasi kepada mahasiswa tentang Aplikasi Padlet secara menyeluruh sehingga siswa bsia memahami tentang sistem Aplikasi Padlet. Solusi bagi permasalahan dalam Implementasi Aplikasi Padlet untuk mengatasi beberapa masalah tersebut di atas, terdapat beberapa solusi yang diambil oleh dosen di kelas menulis. Pertama, Dosen memberikan pengarahan dan penjelasna bebrapa kali terkait penggunaan dan pemanfaatan fitur- fitur Padlet. Konsultasi secara satu persatu juga dilayani bagi yang mengalami kesulitan. Berikutnya, dosen secara konsisten mengarahkan 
mahasiswanya untuk belajar bahasa Inggris khususnya dalam penulisan karangan dan esai tidak hanya Ketika di kelas online. Evaluasi oleh dosen terus dilakukan baik saat bertemu dengan mahasiswa di kelas dan bahkan saat sebelum memulai kelas.

Beberapa kendala dalam mendaftar, mengumpulkan tugas dievaluasi di kelas. Dosen mengklarifikasi bahwa dengan evaluasi di kelas akan membuat pemahaman materi menjadi lebih baik. Dosen mengidentifikasi masalah yang terjadi oleh mahasiswa; Dosen memberikan arahan kepada mahasiswa agar mahasiswa paham tentang sistem dalam aplikasi Padlet. Dosen juga mengevaluasi isi tugas saat memberikan kuliah di kelas.

Untuk mengatasi beberapa masalah seperti mendaftar dan mengumpulkan tugas yang dibutuhkan, dosen melakukan praktik di depan kelas untuk membuat mahasiswa lebih paham. Dosen juga mengklarifikasi lagi akan cara memaksimalkan Padlet dengan gamblang dan mengatasi permasalahan siswa, guru bertanya kepada siswa bagian apa yang membuat siswa bingung dan dosen menyelesaikan masalah tersebut.

Solusi kedua terkait peningkatan kualitas isi tulisan yang disubmit mahasiswa, dosen melakukan evaluasi secara kontinu dan melakukan penilaian di dalam kelas. Dosen menilai dan mengecek isi tulisan di kelas bersama mahasiswa, sehingga mahasiswa tahu betul dimana letak kekurangan dan kesalahan mereka. Solusi ketiga untuk menyelesaikan masalah terkait dengan kesulitan dalam fase freewriting dalam brainstorming ide adalah dengan meminta mahasiswa mencari referensi di Aplikasi Padlet. Untuk mengatasi masalah tersebut siswa akan melihat beberapa sumber tugas dari teman-teman yang telah menyerahkan tugas terlebih dahulu di Aplikasi Padlet. Meskipun dengan topik yang berbeda, hal itu akan dapat membantu siswa membangun ide dri awal dalam prewriting hingga brainstorming.

Solusi terakhir untuk mengatasi masalah koneksi atau jaringan internet yang buruk adalah dengan memanfaatkan WIFI (baik di rumah maupun di kampus). Untuk mengatasi masalah dengan koneksi web, Dosen dan mahasiswa sebelumnya sepakat bahwa saat mahasiswa masuk dalam aplikasi Padlet, mereka sudah masuk ke dalam kampus (sebelum pandemi) karena koneksi web di kampus tinggi, siswa tidak akan mendapatkan masalah terkait koneksi web. Selama masa pandemi, mahasiswa diminta mencari spot terbaik untuk bisa mendapatkan jaringan terbaik atau bisa juga mencari sumber Wifi untuk jaringan yang lebih baik. Pada akhirnya, selain terdapatnya kestabilan jaringan internet, kombinasi yang bagus antara kemampuan 
dosen dalam menggunakan dan memanfaatkan Aplikasi padlet di kelas menulis serta kemampuannya dalam menggerakkan antusiasme mahasisea menjadi faktor penting dan penentu dalam kesuksesan Implementasi aplikasi Padlet di kelas menulis. Fitur- fitur Padlet yang memungkinkan adanya interaksi antara dosen dan mahasiswa serta antar mahasiwa menjadi kelebihan yang bisa dimanfaatkan dalam pengajaran menulis. Kegiatab menulis menjadi lebih menantang dan menyenangkan dengan menggunakan Padlet.

\section{Kesimpulan}

Implementasi Aplikasi Padlet di kelas menulis dapat memberikan hasil yang positif. Dalam kelas menulis, Padlet bisa digunakan sebagai media pelengkap untuk membantu siswa dalam diskusi tentang materi pelajaran menulis. Dosen melakukan beberapa tahapan yang meliputi perencanaan, proses belajar-mengajar dan evaluasi. Aplikasi Padlet dapat digunakan untuk presentasi dan penyampaian materi, pemberian tugas pada aplikasi Padlet dan mengumpulan respons. Dalam implementasinya, Dosen memposisikan dirinya sebagai fasilitator mulai dari memposting materi pembelajaran, tugas siswa dan diskusi topik di Padlet. Melalui fungsi ini, dosen bisa memanfaatkan
Aplikasi Padlet untuk memaksimalkan proses pengajaran, membuat mahasiswa menjadi lebih aktif (student centre) sehingga bisa memantik mahasiswa menjadi autonomous learners (pebelajar yang lebih mandiri). Diantara beberapa kecakapan dalam menulis, brainstorming (proses pengeluaran ide) merupakan kecakapan yang paling berkembang dengan menggunakan Aplikasi Padlet ini.

Permasalahan yang terjadi dalam implementasi Aplikasi padlet in adalah kurang fahamnya mahasiswa akan semua fungsi fitur yang tersedia. Hal ini mengakibatkan kurang maksimalnya pemanfaatan Padlet. Dosen sebagai fasilitator, memegang peranan penting dalam hal ini, pemberian penjelasan dan simulasi di awal sebelum perkuliahan menjadi hal yang penting untuk dilakukan sebelum menggunakan Padlet. Meningkatkan keterampilan mahasiswa dalam menggunakan media, perlu menjadi fokus. Hal ini untuk memastikan bahwa seluruh mahasiswa telah siap memanfaatkan seluruh fitur aplikasi sebelum perkuliahan dimulai.

Lebih lanjut masalah jaringan yang merupakan masalah klasik bagi pebelajar di Indonesia menunjukkan bahwa fasilitas yang terkait dengan jaringan Internet ini perlu menjadi perhatian khusus bagi pengguna Aplikasi Padlet. Tanpa sarana 
(jaringan) yang mumpuni, sebagus apapun teknologi, akan sulit untuk bisa memberikan hasil yang maksimal.

\section{Daftar Pustaka}

Abu Ahmadi dan Nur Uhbiyat. 2001. Ilmu Pendidikan. Jakarta: Rineka cipta.

Algraini, Farah. 2014. The Effect of Using Padlet on Enhancing EFL Writing Performance. Disetasi M.A diterbitkan. Saudi Arabia: College of Languages and Translation AlImam Muhammad Ibn Saud Islamic University.

Arsyad, Azhar. 2006. Media Pembelajaran. Jakarta. PT: Rajawali Press.

Brown, H. Douglas. 2001. Teaching by Principles: An Interactive Approach to Language Pedagogy (Second Edition). New York: Longman.

Brown, H. Douglas. 2004. Language Assessment: Principle and Classroom practice. London: Longman.

Deni, R. A., \& Zainal, Z. 2015. Let's write on the wall: collaborative learning using Padlet. The Turkish Online of Educational Technology, 2(1):364-369.

Fiester, H. \& Green, T. 2016. Student use of backchannels. Tech Trends, (Online) 60(4):404-408, (Doi: http://dx.doi.org10.1007s11528016-0069-9/, diakses 17 Januari 2019).
Harris D. P. 1969. Testing English as a Second Language. New York: Mc. Graw-Hill Book Company

Haris, M, Yunus, M, Md, \& Hj Badusah, J. 2017. The Effectiveness of Using Padlet in ESL Classroom. International Journal of Advanced Research, 5(2):783788.

Harmer, Jeremy. 2004. How to Teach Writing. New York: Pearson Education Limited.

Harmer, Jeremy. 2007. How to Teach English (new edition). New York: Pearson Education Limited.

Langan, John. 2005. College writing skills. New York: McGraw-Hill.

Milles, M. B and Huberman, A. Michael. 1984. Qualitative data analysis: A sourcebook of new methods. Beverly Hills: Sage Publication.

Nunan, David. 1995. Closing the gap between learning and instruction. TESOL Quarterly, 29(1), 133158.

Nunan, David. 2003. Practical English Language Teaching. New York: McGraw Hill.

Nunan, David. 2005. Practical English Language Teaching: Young Learners. New York: McGraw Hill.

Russsel, Carol and John Shepherd. 2005. Online Role Play Environments for higher Education. British Journal of Education Technology, Vol 4, No 6. 
Shield, J. 2014.Virtual Toolkit. Screen Education, 75:92-93.

Sugiyono. 2015. Metode Penelitian Pendidikan (Pendekatan Kuantitatif, Kualitatif and $R \& D$ ). Bandung: Alfabeta.

Sutopo, H.B. 2006. Penelitian kualitatif dasar teori dan terapannya dalam penelitian. Surakarta: Sebelas Maret University.

Surakhmad, Winarno. 1994. Pengantar Penelitian Ilmiah: Dasar Metode Teknik. Bandung: Tarsito Press

Sutopo, H.B. 2006. Penelitian kualitatif dasar teori dan terapannya dalam penelitian. Surakarta: Sebelas Maret University.

Togatorop, Erikson. 2015. Teaching Writing with a Web Based Collaborative Learning. International Journal of Economics and Financial Issues (IJEFI), (5): 247-256

Westwood, Peter. 2004. Learning and Learning Difficulties: A Handbook for Teachers. Hongkong: Acer Pres. 